\title{
NUMERICAL APPROACH IN RECOGNITION OF SELECTED FEATURES OF ROCK STRUCTURE FROM HYBRID HYDROCARBON RESERVOIR SAMPLES BASED ON MICROTOMOGRAPHY
}

\author{
ŁUKASZ DOMINIK KACZMAREK \\ University of Warsaw, Faculty of Geology, e-mail: lukasz.kaczmarek@uw.edu.pl \\ YUFENG ZHAO, HEINZ KONIETZKY \\ TU Bergakademie Freiberg, Faculty of Geosciences, Geoengineering and Mining \\ TOMASZ WEJRZANOWSKI, MiCHAŁ MAKSIMCZUK \\ Warsaw University of Technology, Faculty of Materials Science and Engineering
}

\begin{abstract}
The study employs numerical calculations in the characterization of reservoir sandstone samples based on high-resolution X-ray computed microtomography. The major goals were to determine porosity through pore size distribution, permeability characterization through pressure field, and structure impact on rock strength by simulation of a uniaxial compression test. Two Miocene samples were taken from well S-3, located in the eastern part of the Carpathian Foredeep. Due to the relation between sample size and image resolution, two X-ray irradiation series with two different sample sizes were performed. In the first approach, the voxel side was $27 \mu \mathrm{m}$ and in the second it was up to $2 \mu \mathrm{m}$. Two samples from different depths have been studied here. Sample 1 has petrophysical features of conventional reservoir deposits, in contrast to sample 2 . The approximate grain size of sample 1 is in the range $0.1-1.0 \mathrm{~mm}$, whereas for sample 2 it is $0.01-0.1 \mathrm{~mm}$ with clear sedimentation lamination and heterogenic structure. The porosity, as determined by $\mu \mathrm{CT}$, of sample 1 is twice $(10.3 \%)$ that of sample $2(5.3 \%)$. The equivalent diameter of a majority of pores is less than $0.027 \mathrm{~mm}$ and their pore size distribution is unimodal right-hand asymmetrical in the case of both samples. In relation to numerical permeability tests, the flow paths are in the few privileged directions where the pressure is uniformly decreasing. Nevertheless, there are visible connections in sample 1, as is confirmed by the homogenous distribution of particles in the pore space of the sample and demonstrated in the particle flow simulations. The estimated permeability of the first sample is approximately four times higher than that of the second one. The uniaxial compression test demonstrated the huge impact of even minimal heterogeneity of samples in terms of micropores: 4-5 times loss of strength compared to the undisturbed sample. The procedure presented shows the promising combination of microstructural analysis and numerical simulations. More specific calculations of lab tests with analysis of variable boundary conditions should be performed in the future.
\end{abstract}

Key words: compression test, flow paths, porosity, sandstone

\section{INTRODUCTION}

In heterogenic material such as rocks, the properties are strongly influenced by the structure. Both structure and properties can nowadays be characterized in more detail due to the progress in equipment development. One of the modern research techniques is high-resolution computed microtomography $(\mu \mathrm{CT})$ which can be favorably used in rock fluid storage and permeability recognition as well as geotechnical study of structure impact on rock strength.

The $\mu \mathrm{CT}$ has a long history, grounded in medicine ([8], [20], [22]). After a few decades its applications widened (e.g., [21], [27], [28], [29]). The step by step nature of $\mu \mathrm{CT}$ use in the field of geosciences, involving data acquisition, reconstruction process and image processing field, was described in some depth by [2], [9], [17]. The major advantage of $\mu \mathrm{CT}$ is its ability to study rock internal structure ([1], [3], [4], [13], [18]). The structure details supplied by $\mu \mathrm{CT}$ even makes it pos- 
sible to identify the species of index fossils and so the stratigraphy correlation of reservoir formation [15]. [25] showed that modeling flow through fractures is a key component in the recovery mechanisms of hydrocarbon transport from naturally fractured reservoirs. Hence, recognition of the internal structure of fractures is fundamental. They also indicate that the rock matrix structure is a storage capacity factor. Furthermore, in paper [10] concerning digital permeability tests, the importance of imaging the pore space was pointed out, especially the contacts between them in the case of lowpermeable samples. In this paper, low-permeable samples without the presence of fractures were used to perform flow simulations through pore space. We analyzed the storage capacity of sandstone samples through studying the porosity as well as flow paths as a transport feature. The impact of structure changes on rock strength was analyzed by numerical simulation of a compression test. [19] showed the usefulness of such analysis. Now, through $\mu \mathrm{CT}$, the accuracy of results is optimized.

The research question is about the utility of combining $\mu \mathrm{CT}$ internal structure recognition and further numerical calculations with regard to sandstone samples from a hybrid hydrocarbon reservoir. Numerical calculations produce detailed analyses of storage capacity and provide a basis for further analysis of transport properties. An important related issue is the impact of structure on rock strength. In order to analyze it after simulation of absolute permeability, uniaxial compression tests were performed.

\section{MATERIALS AND METHODOLOGY}

The samples come from a hydrocarbon source rock area, which is still prospective for commercial production (borehole S-3, SE part of the Husów gas field). This is the eastern part of the Carpathian Foredeep. The Miocene sandstone samples were cut from core material, from a depth of $1920.45 \mathrm{~m}$ in the case of sample 1 and $1923.95 \mathrm{~m}$ in the case of sample 2 . They belong to siliciclastic sediments of the heterolithic facies. These deposits feature thin-bedded sandstones, mudstones and siltstones. There are many cases of structural traps in these facies, which contain huge amounts of oil and gas [23]. [24] suggested that the presence of a significant concentration of hydrocarbons in heterolithic reservoirs with poor capacity and permeability properties is the proof of accumulations of unconventional hydrocarbon. The selected samples are relevant examples of different sandstone structures, despite the proximity of deposition. Sample 1 has the petrophysical features of conventional reservoir deposits, in contrast to sample 2, which has more unconventional features. Therefore, the deposit can be considered as a hybrid reservoir. Figure 1 shows the cylindrical samples which were tested. The analyzed material was descripted in detail in [14] and [26].
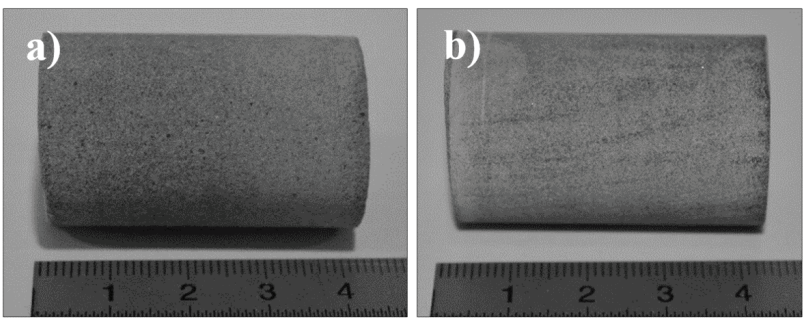

Fig. 1. Photos of analyzed Miocene sandstone samples: A - Sample 1, B - Sample 2

Figure 2 shows the workflow of the study performed.

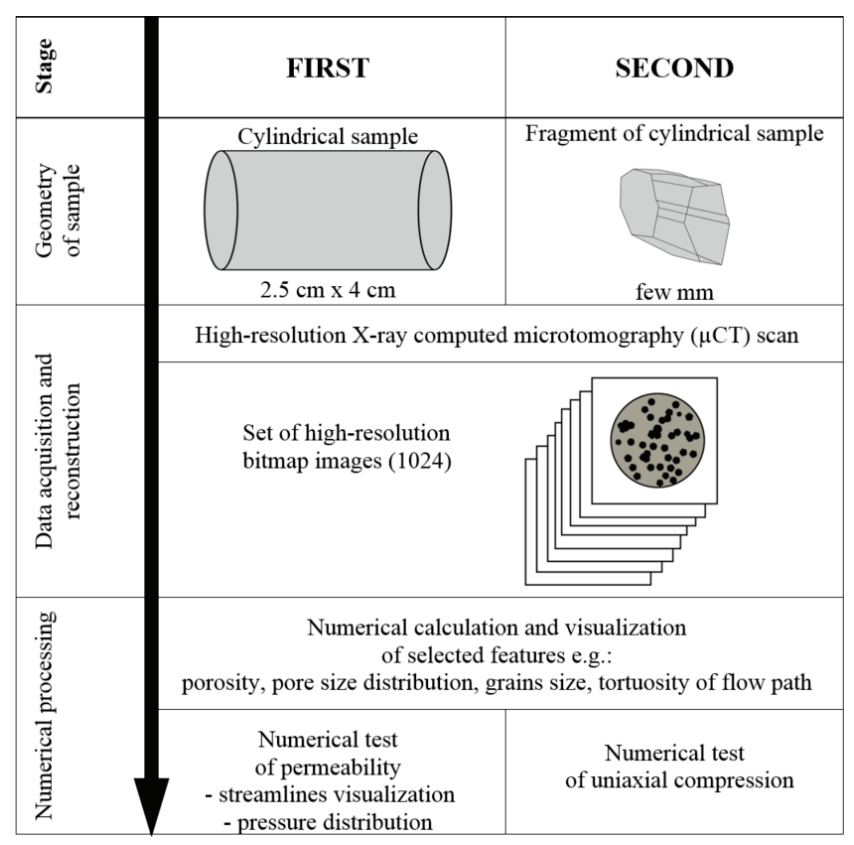

Fig. 2. Workflow of sandstone sample study

The crucial component of numerical calculations is data quality. The non-destructive and non-invasive method of $\mu \mathrm{CT}$ enables fast and easy recognition of internal structures. A key result of $\mu \mathrm{CT}$ is the numerical model, which can be used in the following numerical simulations. $\mu \mathrm{CT}$ is a method which is based on the linear attenuation coefficient $\left(\kappa, \mathrm{cm}^{-1}\right)$, which represents the probability of absorption of a photon beam per unit path length [7]. It is the function of the density of the absorbing material $\left(\rho, \mathrm{g} \mathrm{cm}^{-3}\right)$. In the case of complex material, $\kappa$ correlates with the totality of chemical elements [16] 


$$
\kappa=\Sigma \kappa_{i} w_{i},
$$

$w_{i}$ - weight fraction of component $i$ in the absorbing material.

Based on transformation [6] linear attenuation coefficient results from

$$
\kappa=\mu_{s} \rho_{s}+\mu_{w} \theta \rho_{w},
$$

$\mu_{s}$ - solid material mass attenuation coefficient $\left(\kappa / \rho, \mathrm{cm}^{2} \mathrm{~g}^{-1}\right)$,

$\rho_{s}$ - density of solid material $\left(\mathrm{g} \mathrm{cm}^{-3}\right)$,

$\mu_{w}$ - water mass attenuation coefficient $\left(\kappa / \rho, \mathrm{cm}^{2} \mathrm{~g}^{-1}\right)$,

$\rho_{w}$ - density of water $\left(\mathrm{g} \mathrm{cm}^{-3}\right)$,

$\theta$ - volumetric rock water content $\left(\mathrm{cm}^{3} \mathrm{~cm}^{-3}\right)$.

Based on this equation rock bulk density and rock water content can be determined. In this study, the samples were dry, so the water content was minimized. During $\mu \mathrm{CT}$ scanning the change of X-ray intensity is registered, which is related to attenuation coefficient by the relation

$$
\Delta I=-\kappa I \Delta x,
$$

$\Delta I$ - change in intensity of $\mathrm{X}$-ray beam interacting with absorber of thickness (keV),

$\Delta x$ - absorber of thickness (cm).

Hence, we can assume that the X-ray intensity changes, and so attenuation coefficient changes indicate density changes. In $\mu \mathrm{CT}$ images those changes are correlated with gray scale values: the lighter zones of image equate to higher density. Hence, we can identify pores and fractures, which are black on $\mu \mathrm{CT}$ images. Such information provides us with knowledge about structure heterogeneity.

Two series of $\mu \mathrm{CT}$ scans were performed in the first stage of this study. The pixel size of radiographs (i.e., initial images created during $\mu \mathrm{CT}$ scans) is related to the size of the sample: the smaller the sample, the smaller the pixel size and hence the better the quality of images and the more accurate the digital model of the sample. During the first approach the cylindrical sample was scanned. The sample size was around $2.5 \mathrm{~cm} \times 4 \mathrm{~cm}$ and so the resolution was around $27 \mu \mathrm{m}$. In the second approach, the small fragments of cylindrical samples were scanned. Hence, the pixel size was much smaller, up to $2 \mu \mathrm{m}$. Consequently, the individual sandstone grains as well as pores could be clearly seen. The technical scan parameters were: image resolution $1024 \times 1024$; power $10 \mathrm{~W}$; copper filter (1.5 mm thickness); Large Field of View type of lens. The data acquisition process was described in detail by [2], [17], and in [9]. Numerical processing was performed, after the data acquisition and reconstruction of $1201 \mu \mathrm{CT}$ images (cross-sections of sam- ples). Firstly, the capacity parameters of sandstone were identified: porosity and pore size distribution. Pore size distributions were calculated by means of equivalent diameter of maximum size sphere matched to pores (Fig. 3).

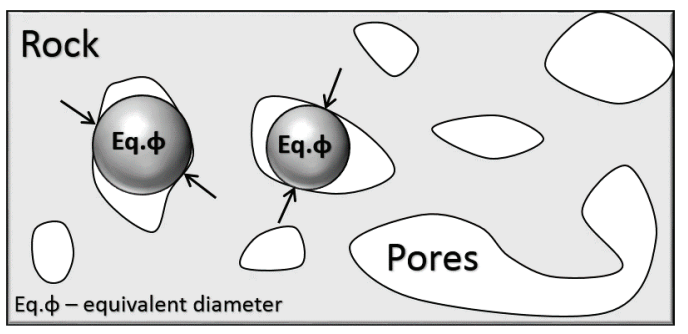

Fig. 3. Scheme of the equivalent diameter

Then, the tortuosity of fluid paths was calculated using Avizo software. In relation to the software calculation procedure, this parameter is the ratio of the real length of the flow path to the straight line between the start and the end of flow (Fig. 4).

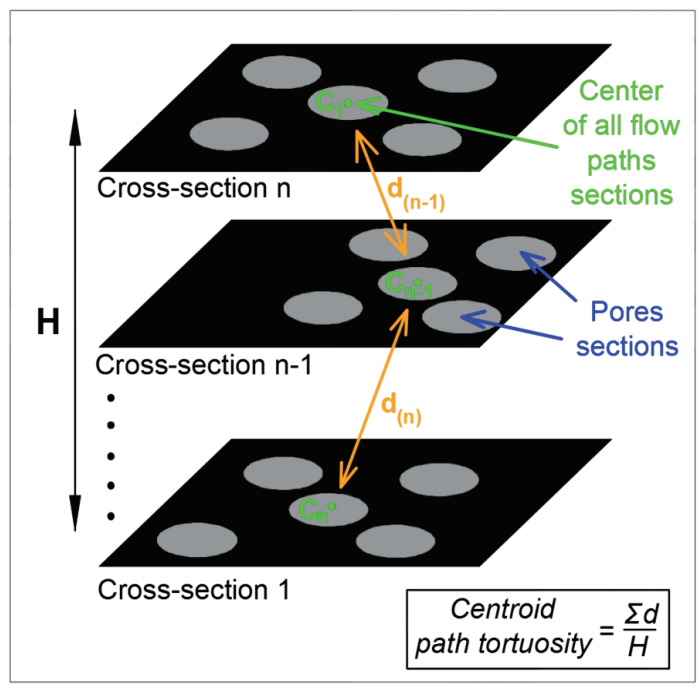

Fig. 4. Schematic diagram of centroid path tortuosity calculation

Finally, the numerical simulations of fluid flow and mechanical compression were performed. $\mathrm{Nu}$ merical simulations of fluid flow and the subsequent visualization of streamlines (flow paths) with pressure distribution were performed using the Finite Volume Method (FVM) employing the developed $\mu$ CT 3-D model. In this study, the flow was simulated using Avizo software and Darcy's law.

$$
\frac{Q}{S}=-\frac{k}{\mu} \cdot \frac{\Delta P}{L},
$$

$Q$ - global flow rate that goes through the porous medium $\left(\mathrm{m}^{3} \cdot \mathrm{s}^{-1}\right)$, 
$S$ - cross-section of the sample the fluid goes through $\left(\mathrm{m}^{2}\right)$,

$k$-absolute permeability $\left(\mathrm{m}^{2}\right)$,

$\mu$-dynamic viscosity of the flowing fluid (Pa.s),

$\Delta P$ - pressure difference applied around the sample $(\mathrm{Pa})$,

$L$ - length of the sample in the flow direction (m).

The fluid flow calculations were performed iteratively, preceded by meshing the geometrical model. Simplified Navier-Stokes equations are used. The numerical analysis gave the fluid pressure distribution and the streamlines (flow paths presented in the next section). The fluid flow simulations were performed on the basis of small fragments of cylindrical rock samples. The purpose for this was to identify small connection channels between pores.

In this part, $\mathrm{PFC}^{2 \mathrm{D}}$ [12] numerical models were introduced to investigate the uniaxial compressive strength of rock samples. Commonly, researchers built their numerical models by generating the internal structure (mineral composition, voids, pores, microcracks, etc.) in a random and stochastically based manner. After introducing $\mu \mathrm{CT}$, researchers can set-up numerical models 1:1 inlcuding all relevant micro- scopic features [30]. After $\mu \mathrm{CT}$ image processing, slices are used to visualize the distribution of various material inclusions. The three-dimensional models of rock matrix and laminations (formed by small quartzitic grains) were reconstructed by Mimics software. Typical cross-section images of the reconstructed original three-dimensional model were chosen and exported as ASCII-files. Then these ASCIIfiles were imported into $\mathrm{PFC}^{2 \mathrm{D}}$ considering two groups: the rock matrix and the laminations with their specific properties. So, the numerical models of rock samples were generated with real size and accurate composition distribution. The dominating composition of the sample was sandstone with some interbedded laminations. The small grains of quartzite were relatively loose in structure, so laminations in general had lower strength, although the strength of each grain was very high. The contact parameters of the boundary were assigned with the same parameters of the lamination. The numerical simulation technique PFC used is a meshfree method on the basis of the Distinct Element Method. Basic entities are balls and walls. Both of them can be deleted or added at any time. Therefore, holes are just created by deleting the balls.

Table 1. Model parameters in 2D simulation

\begin{tabular}{|c|c|c|c|c|c|c|}
\hline $\begin{array}{c}\text { Model } \\
\text { Element }\end{array}$ & Parameter & $\begin{array}{c}\text { Rock matrix } \\
\text { (sandstone) }\end{array}$ & $\begin{array}{c}\text { Lamination } \\
\text { (small grains } \\
\text { of quartzite) }\end{array}$ & $\begin{array}{l}\text { Model } \\
\text { element }\end{array}$ & Parameter & $\begin{array}{c}\text { Loading } \\
\text { plates } \\
\text { (wall) }\end{array}$ \\
\hline \multirow{3}{*}{ Particles } & $\begin{array}{l}\text { Radius } \\
r[\mathrm{~mm}]\end{array}$ & 0.05 & 0.05 & \multirow{3}{*}{ Walls } & \multirow{3}{*}{$\begin{array}{l}\text { Effective } \\
\text { modulus } \\
E[\mathrm{MPa}]\end{array}$} & \multirow{3}{*}{$8 \times 10^{2}$} \\
\hline & $\begin{array}{c}\text { Density } \\
\rho\left[\mathrm{kg} / \mathrm{m}^{3}\right]\end{array}$ & 2500 & 2700 & & & \\
\hline & $\begin{array}{l}\text { Effective } \\
\text { modulus } \\
E[\mathrm{MPa}]\end{array}$ & $8 \times 10^{2}$ & $8 \times 10^{2}$ & & & \\
\hline \multirow{5}{*}{$\begin{array}{l}\text { Flat-joint } \\
\text { contact } \\
\text { (ball-ball) }\end{array}$} & $\begin{array}{l}\text { Effective } \\
\text { modulus } \\
E_{f j}[\mathrm{MPa}]\end{array}$ & $1.06 \times 10^{4}$ & $3.69 \times 10^{3}$ & \multirow{5}{*}{$\begin{array}{c}\text { Linear } \\
\text { model } \\
\text { (ball-facet) }\end{array}$} & $\begin{array}{c}\text { Normal } \\
\text { stiffness } \\
k_{n}[\mathrm{GPa} / \mathrm{m}]\end{array}$ & 21.2 \\
\hline & $\begin{array}{l}\text { Tension } \\
\text { strength } \\
\sigma_{c}[\mathrm{MPa}]\end{array}$ & 2.28 & 0.29 & & \multirow{2}{*}{$\begin{array}{c}\text { Shear } \\
\text { stiffness } \\
k_{s}[\mathrm{GPa} / \mathrm{m}]\end{array}$} & \multirow[t]{2}{*}{21.2} \\
\hline & $\begin{array}{c}\text { Cohesion } \\
c[\mathrm{MPa}] \\
\end{array}$ & 1.69 & 15.35 & & & \\
\hline & $\begin{array}{c}\text { Friction } \\
\text { coefficient } \mu\end{array}$ & 0.5 & 0.5 & & \multirow{2}{*}{$\begin{array}{c}\text { Friction } \\
\text { coefficient } \mu\end{array}$} & \multirow{2}{*}{0.05} \\
\hline & $\begin{array}{c}\text { Friction angle } \\
\phi\left[^{\circ}\right]\end{array}$ & 43.83 & 47.82 & & & \\
\hline
\end{tabular}

Table 2. Number of particles in each model

\begin{tabular}{|l|c|c|c|c|}
\hline Number of particles $N$ & Model 1-1 & Model 1-2 & Model 2-1 & Model 2-2 \\
\hline Rock matrix (sandstone) & 58918 & 59250 & 59136 & 61440 \\
\hline Lamination (small grains of quartzite) & 0 & 0 & 2304 & 0 \\
\hline
\end{tabular}


Table 3. Calculation model employed during the UCS tests

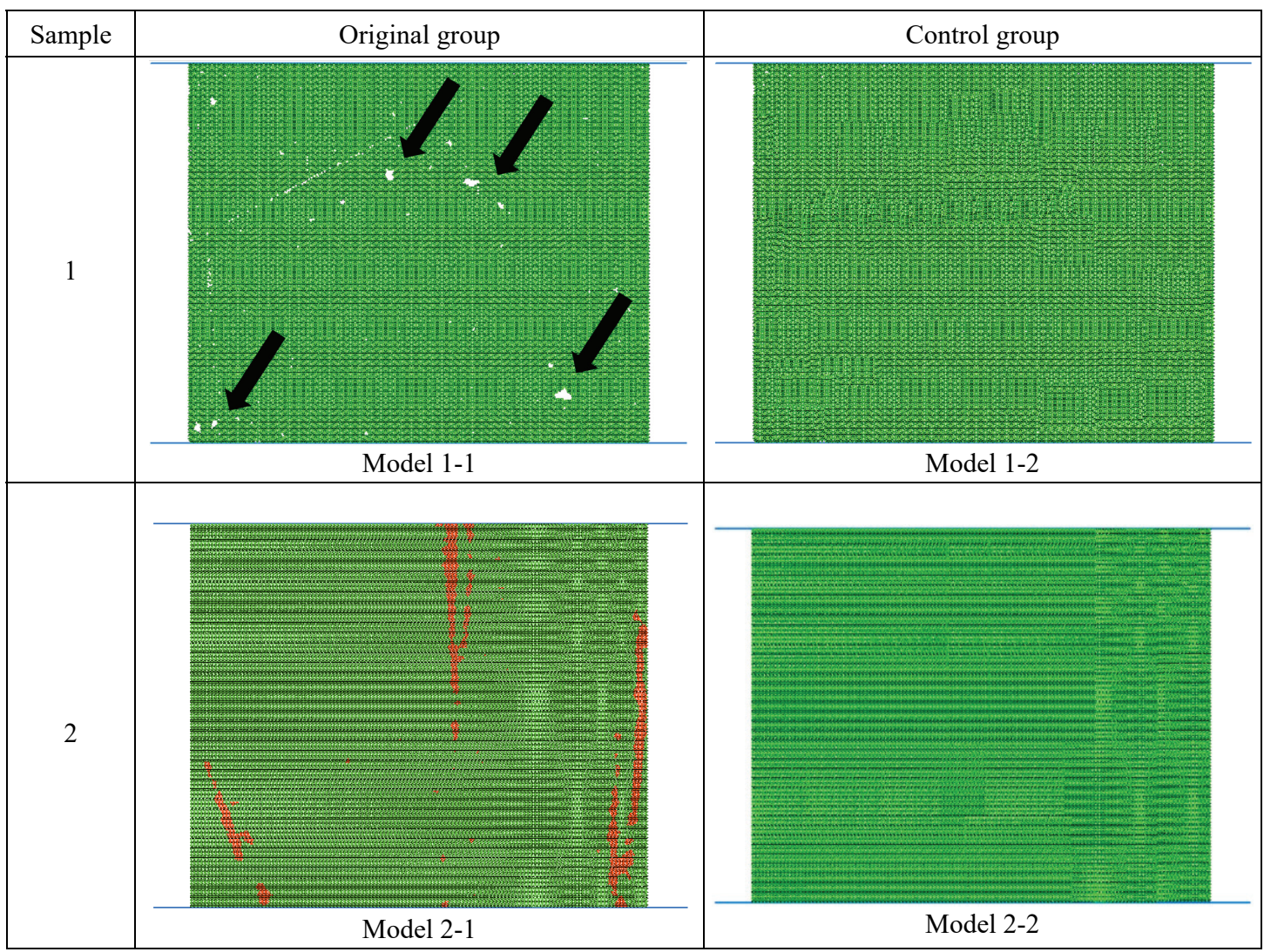

The flat-joint contact model (described in [12]) was introduced to the model, which provides the macroscopic behavior of a finite-size, linear elastic and either bonded or frictional interface that may sustain partial damage. The flat-joint contact model can illustrate the fracture evolution in the model. During the UCS test the static conditions were considered. The constitutive law does not contain any time-dependence. Therefore, loading velocity can deviate from real lab values as long as it is guaranteed, the model is always in quasi-static equilibrium. This was proved by monitoring the unbalanced forces and stresses during the loading. Tables 1 and 2 show the assumed parameters for rock models. The parameters were determined based on lab experience, literature and former research studies ([14], [26]).

In the numerical model, the matrix and the lamination were represented by green and red particles respectively, as shown in Table 3, and the particles occupying the position of the pores were deleted, so the empty spaces in the model represented the pores. In this table, the cross-sections with natural structure of the studied sandstones are named „original group" phrase. The cross-sections with solid and homogenous structure are named „control group”. The simulation of uniaxial compression (UCS) test were activated by moving the top and bottom walls.

\section{RESULTS}

The first result that could be analyzed in relation to the research procedure scheme was structure recognition of cylindrical samples. Table 4 presents the internal cross-section images of both samples. In sample 1 we observed quite big grains (no bigger than $1 \mathrm{~mm}$ ). There are some more dense grains (correlated to white color) and all spectrum of gray color grains. There are no cracks inside, but there are clearly visible pores (dark objects) with single huge pores of up to around $0.6 \mathrm{~mm}$. In this sandstone sample the structure is compact, and the grain size distribution as well as grain density distribution of the sample is uniformly variable. In sample 2, we observed a fine compact grain structure with a size of up to around $0.1 \mathrm{~mm}$. Moreover, there are grains with higher density, which can be observed as white sedimentation laminations. The pores are quiet small, so the equivalent diameter is no bigger than $0.3 \mathrm{~mm}$. In order to obtain better quality images (smaller pixels), fragments of cylindrical samples were scanned. Table 5 shows a compari- 
Table 4. Results of data acquisition and reconstruction of cylindrical samples

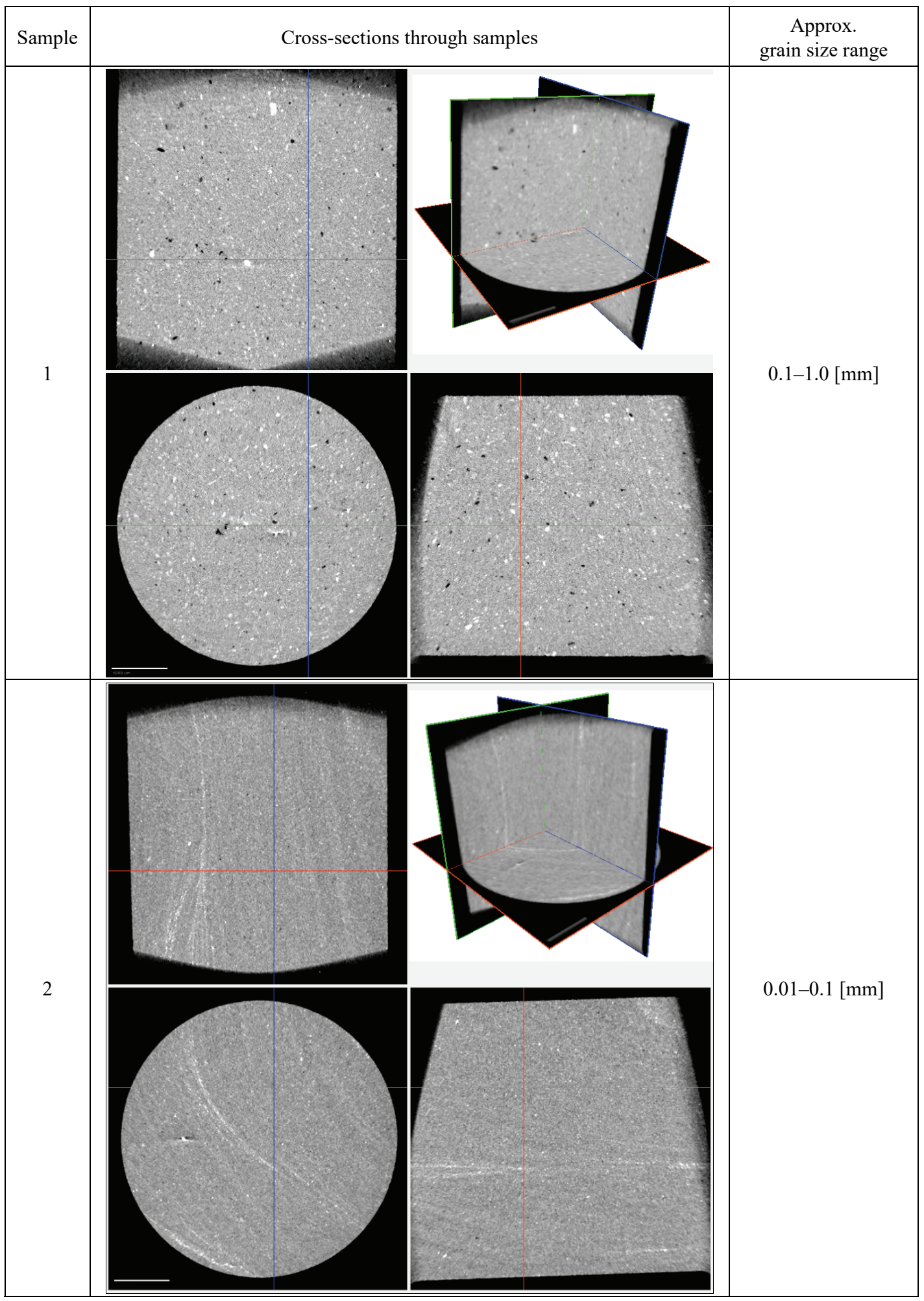

son of cross-sections of cylindrical samples with crosssections of small fragments of these samples. In these stages a 3-dimensional numerical model was generated for further simulations.

The numerical analysis of porosity revealed information about spatial pore distribution, as well as equivalent diameter size fraction (Table 6). Further- more, the pore space is considered as flow path. Hence, the tortuosity of the flow path parameter was calculated. The flow path in the case of sample 1 is around $38 \%$ less tortuous than in sample 2. Figure 5 shows a summary of porosity calculations in two scales, where in one the pixel size (and so voxel size) was $27 \mu \mathrm{m}$ and in the second up to $2 \mu \mathrm{m}$. The porosity, 
Table 5. Results of data acquisition and reconstruction: structure comparison

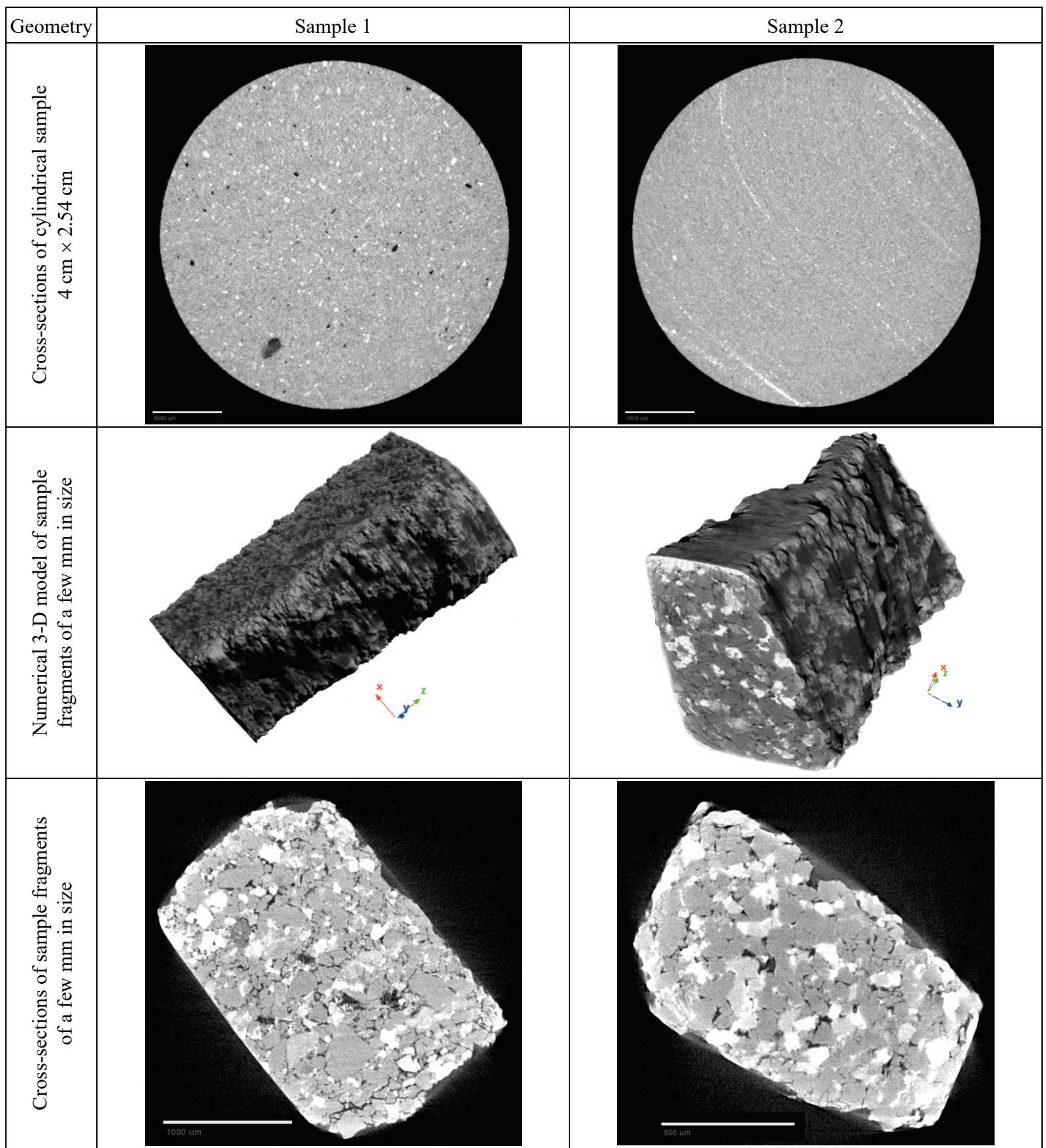

determined by $\mu \mathrm{CT}$, of sample 1 is twice $(10.3 \%)$ that of sample $2(5.3 \%)$. The equivalent diameter of a majority of the pores is less than $0.027 \mathrm{~mm}$ and their pore size distribution is unimodal right-hand asymmetrical in the case of both samples.

After porosity characterization was completed, the numerical permeability tests could be performed. The flow paths are in a few privileged directions, where the pressure uniformly decreases in the case of major paths flow. Nevertheless, in sample 1 there are visible connections, which is confirmed by particles in the whole space of the sample as a result of particle flow.
In the case of dead ends or very thin connection between pores, we observed higher pressure, which can cause damage evolution. Table 7 is a summary table of the results of the numerical permeability tests.

The estimated permeability of the first sample is approximately four times higher than that of the second one. In the present study the results of the permeability calculations should be treated as approximation. Their usefulness is the ability to compare the permeability properties of the various test samples. For more reliable results, calculations should be corrected by taking into account capillary action. 
Table 6. Results of numerical calculation and visualizations

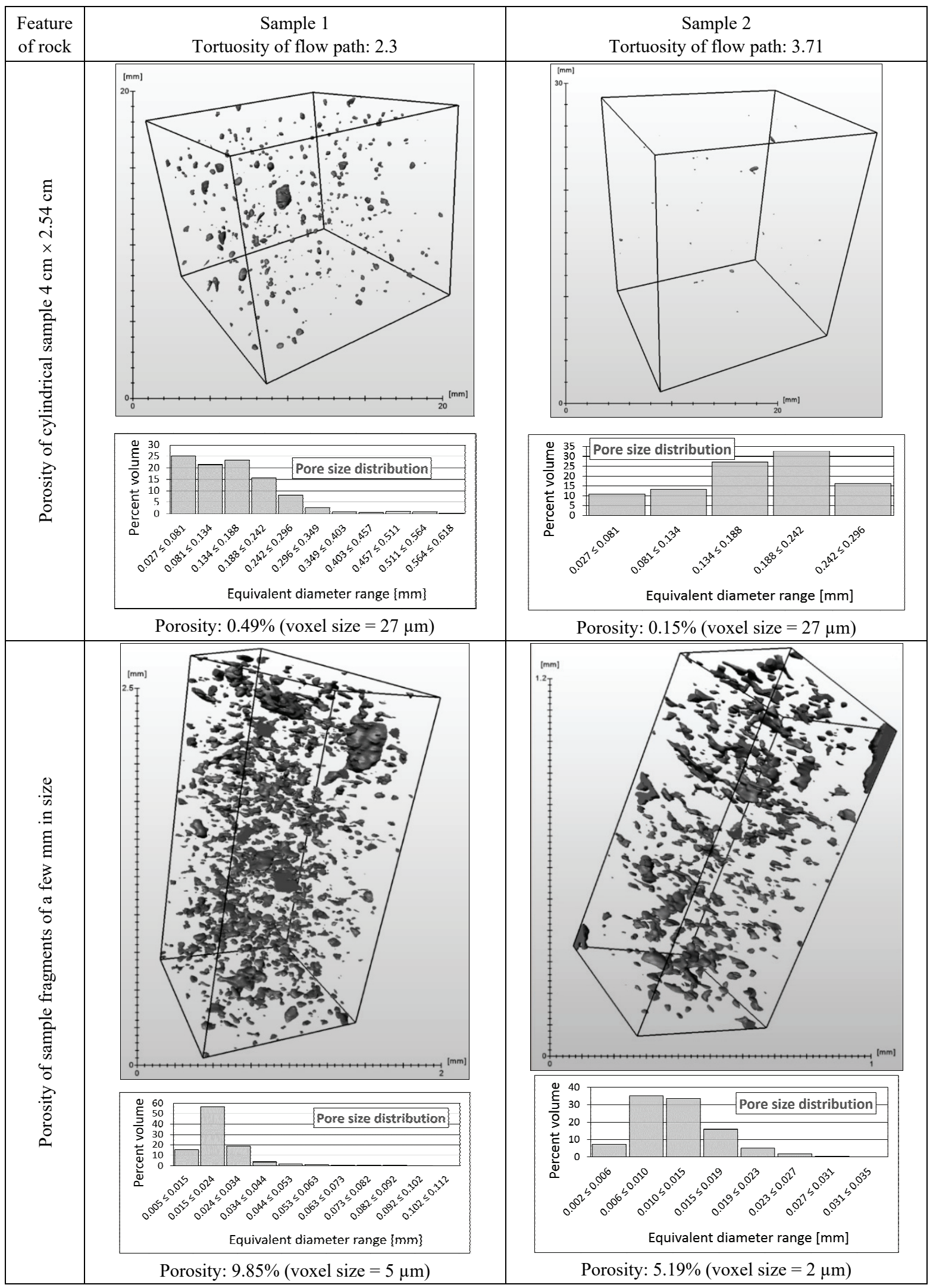

After fluid flow simulation, the UCS tests were performed. Downward velocity to the top wall and upward velocity of the same value to the bottom wall were applied in the UCS. The stress-strain curves were achieved from the simulations, as shown in Fig. 6. Numerical models had the same size and accurate 


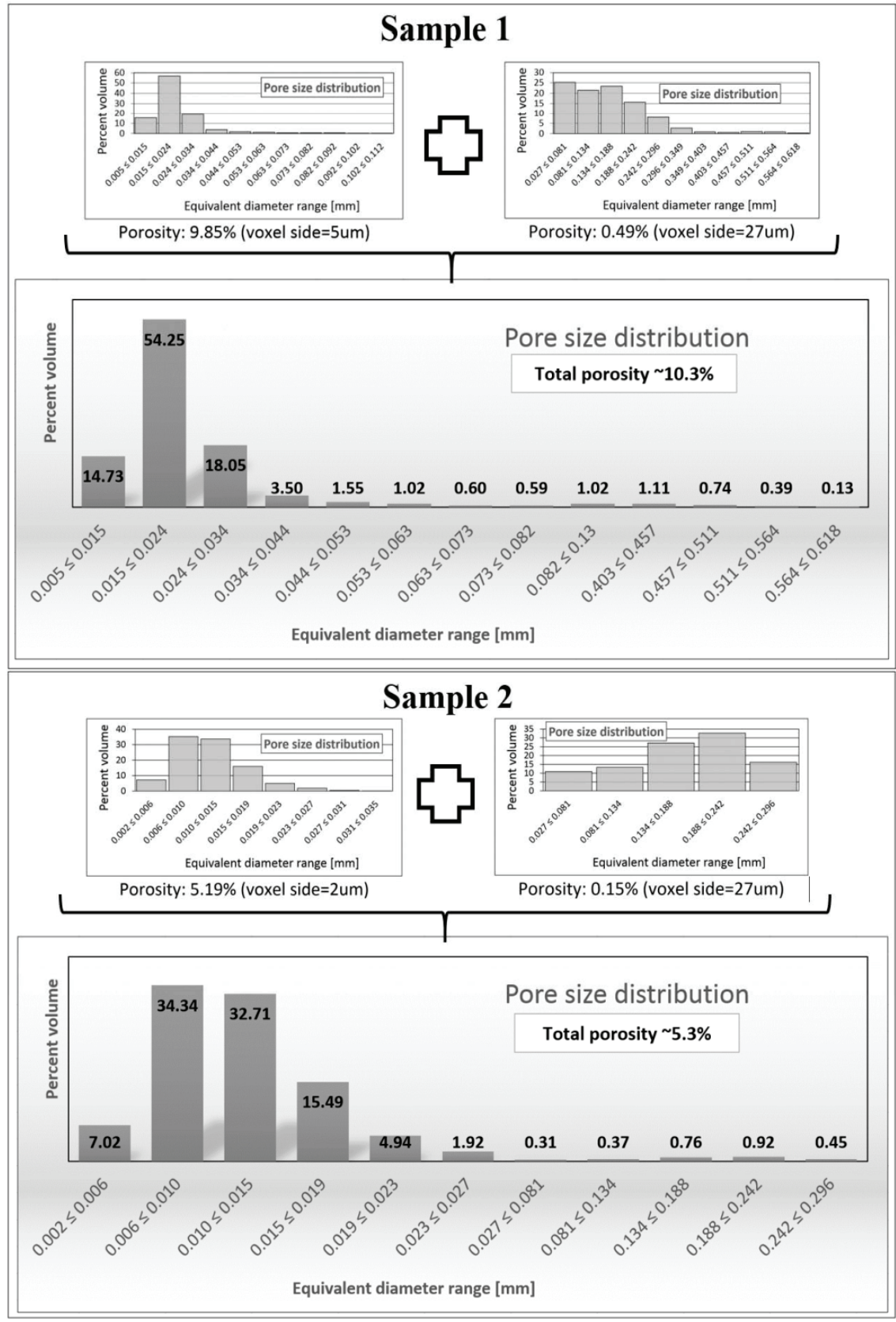

Fig. 5. Total porosity and full pore size distribution of samples 1 and 2

composition distribution of original rock samples. The numerical models were generated based on the central cross-sections of the samples, and simplified as a twodimensional model. In this approach, the structure and mechanical information in the third dimension were ignored. Fracture and crack propagation as well as failure patterns of samples were reproduced via numerical simulations. A control group was set up to investigate the influences of structures. In this part, we generated numerical models with the same dimensions of original heterogeneity samples, but we did not import the geometry files of pores and laminations. By applying the same parameters respectively, the com- parison between model 1-1 and uniform model 1-2 illustrated the influence of pores, and the simulation results of model 2-1 and uniform model 2-2 showed the influence of lamination structure. As shown in Fig. 6 and Table 8, the uniaxial strengths of the porous model and laminated model were much lower than the isotropic control group. The elastic ranges in Fig. 6 are not exactly the same; the curves of the model with pores and the model with laminations had lower gradients than their counterparts in control group. Furthermore, the models with pores and laminations reached the plastic deformation stage much earlier than the control group. 
Table 7. Results of numerical permeability testing

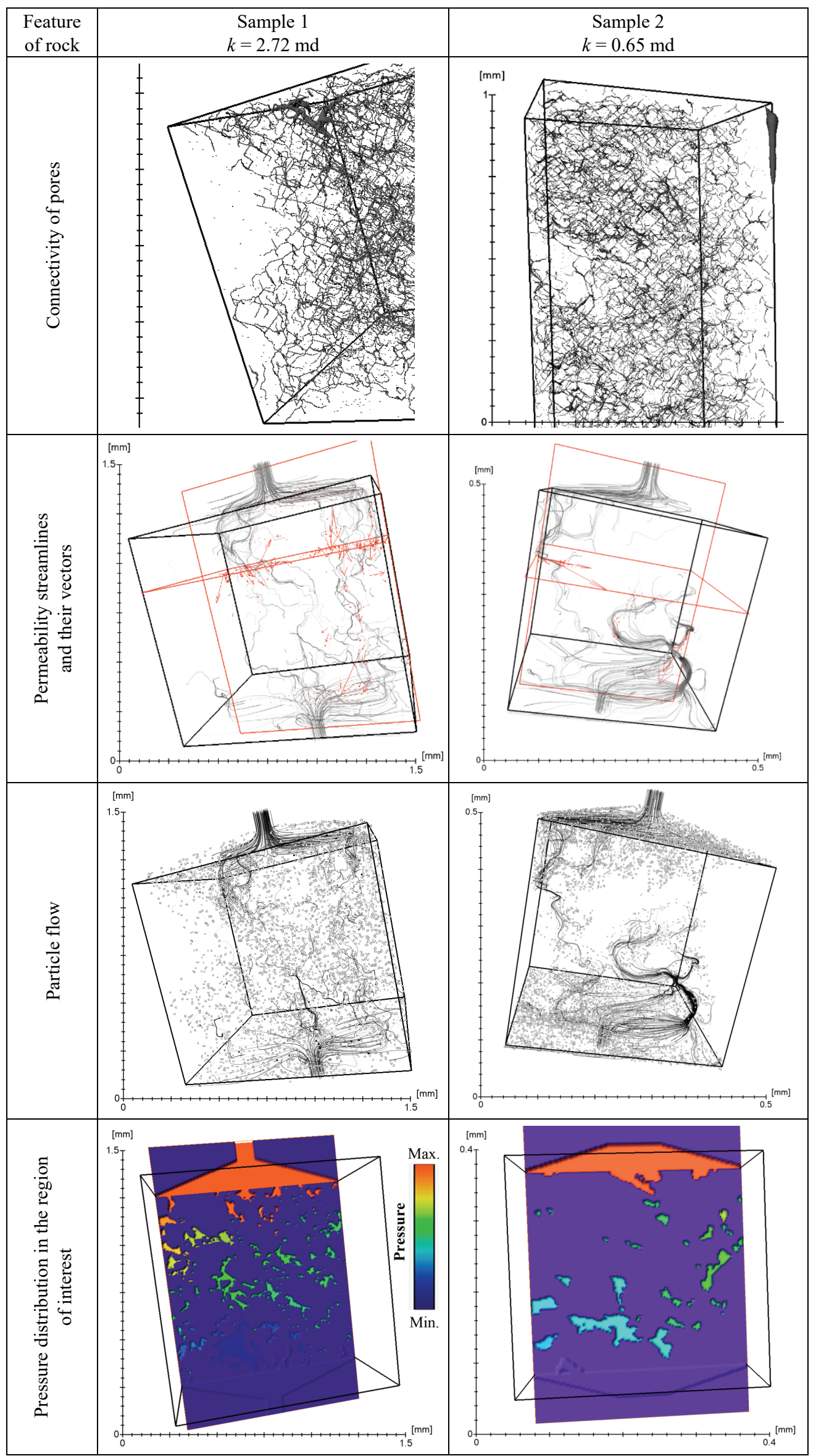



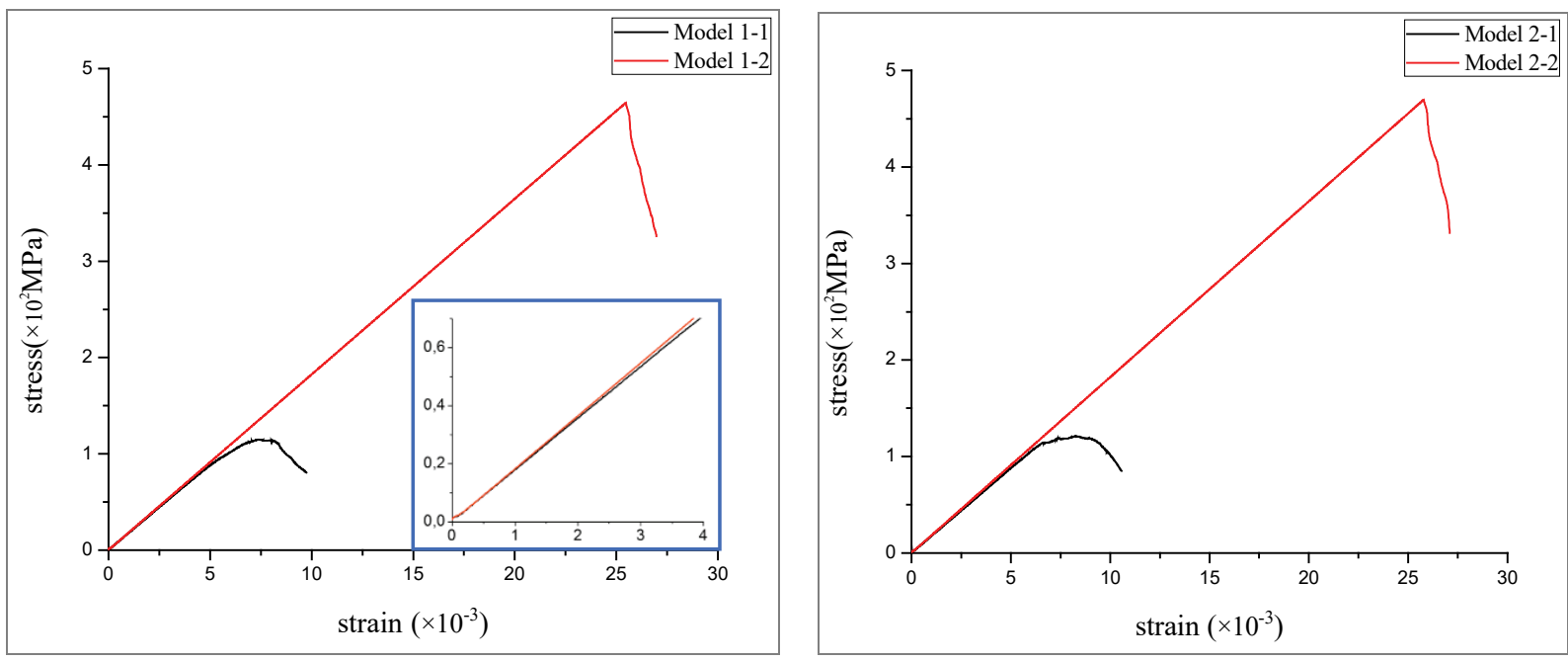

Fig. 6. Stress-strain-curved obtained from numerical UCS tests

Table 8. Uniaxial compressive strength of rock models

\begin{tabular}{|c|c|c|c|}
\hline Model 1-1 & Model 1-2 & Model 2-1 & Model 2-2 \\
\hline $1.15 \times 10^{2} \mathrm{MPa}$ & $4.64 \times 10^{2} \mathrm{MPa}$ & $1.21 \times 10^{2} \mathrm{MPa}$ & $4.70 \times 10^{2} \mathrm{MPa}$ \\
\hline
\end{tabular}

Table 9. Stress-strain curves obtained from numerical UCS tests with marked points representing different moments of stress field

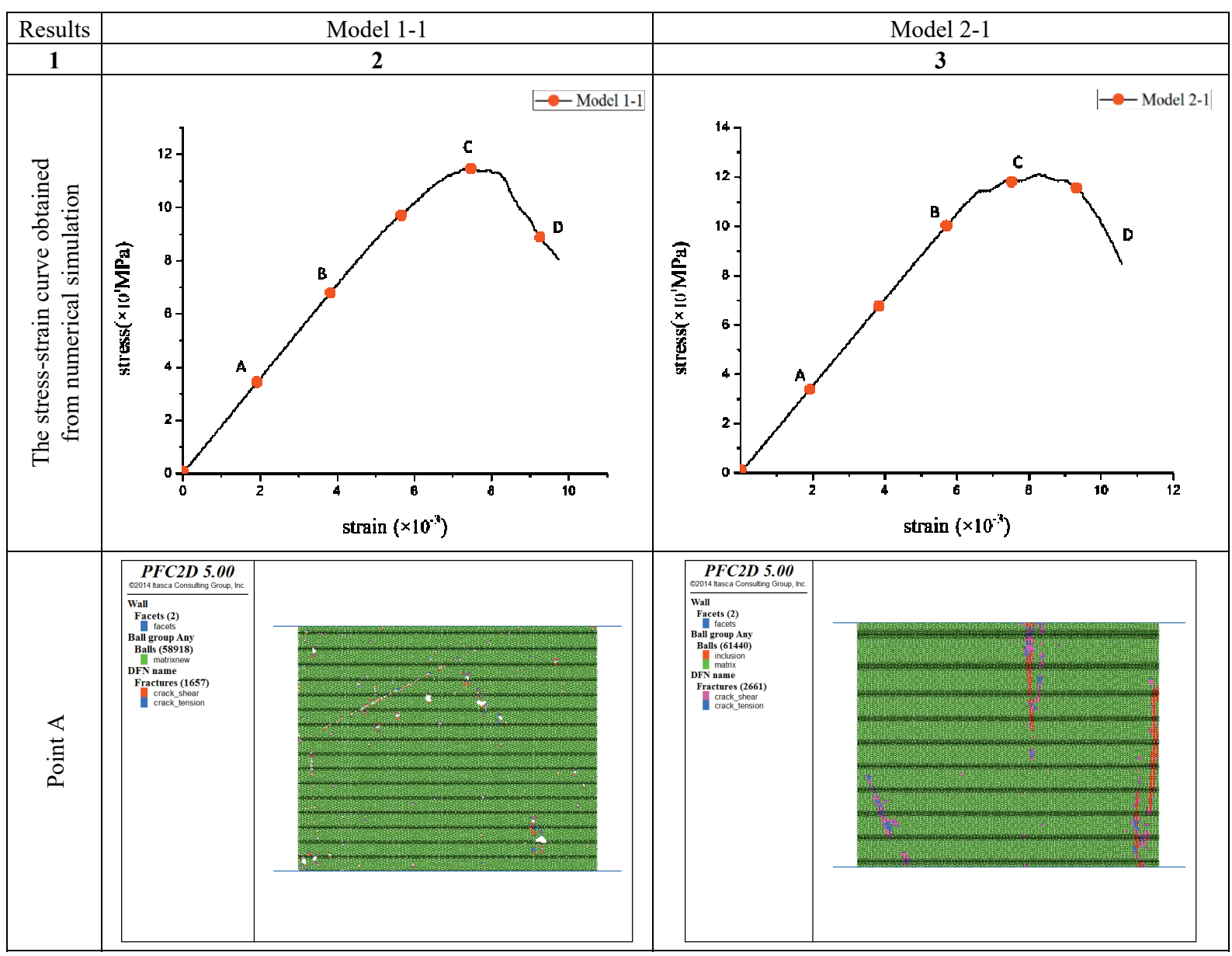




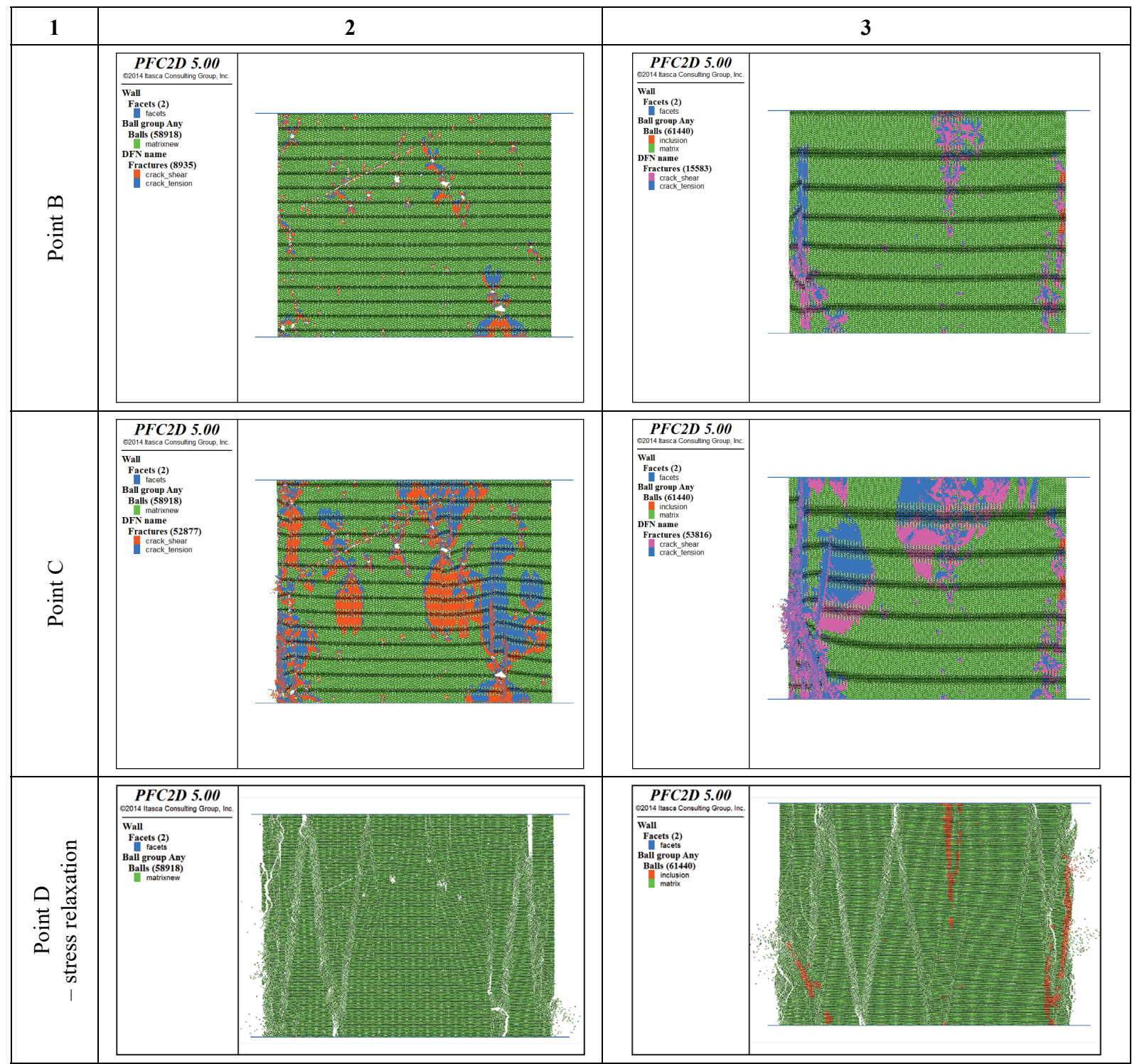

Table 9 shows stress-strain curve as well as the fracture pattern during uniaxial compression simulations. It becomes obvious that the internal structure of the samples (i.e., pores and laminations) is the key factor for damage evolution and have significant influence to the strength of the samples.

\section{SUMMARY}

Numerical calculations based on $\mu \mathrm{CT}$ results revealed storage and permeability features of a hybrid sandstone hydrocarbon reservoir. The numerical compressive strength simulations revealed the impact of structure heterogeneity on rock strength. The outlined procedure provides a universal way to evaluate structural features and their impact on the hydraulical and mechanical behavior. Two Miocene samples were taken from well S-3, located in the eastern part of the Carpathian Foredeep. Due to the relation between sample size and image resolution, two X-ray irradiation series were performed with two different sample sizes. In the first approach, the voxel side was $27 \mu \mathrm{m}$, and in the second up to $2 \mu \mathrm{m}$. Sample 1 has petrophysical features of conventional reservoir deposits, in contrast to sample 2. The approximate grain size of sample 1 is in the range $0.1-1.0 \mathrm{~mm}$ and for sample 2 it is $0.01-0.1 \mathrm{~mm}$ with clear sedimentation lamination and heterogenic structure. The porosity, determined by $\mu \mathrm{CT}$, of sample 1 is twice $(10.3 \%)$ that of sample $2(5.3 \%)$. The equivalent diameter of a majority of pores is less than $0.027 \mathrm{~mm}$ and their pore size distribution is unimodal right-hand asymmetrical in both samples. In relation to numerical permeability tests, the flow paths are in a few privileged directions, where the pressure uniformly decreases. Nevertheless, in 
sample 1 there are visible connections, which is confirmed by particles in the whole space of the sample, as the simulation of particle flow has shown. The estimated permeability of the first sample is approximately four times higher than that of the second one. The uniaxial compression test demonstrated the huge impact of even minimal heterogeneity of samples, 4-5 times loss of strength compared to the uniform sample. More specific calculations of lab tests with analysis of variable boundary conditions as well as parametric and back analysis should be carried out in the future. The potential of $\mu \mathrm{CT}$ has been extended into the field of petrophysical and geomechanical science.

\section{ACKNOWLEDGEMENTS}

The authors are much indebted to the Polish Oil and Gas Company (PGNiG) for providing core samples. The samples on which the research was based were taken by Dr. Grzegorz Machowski, whom the authors would also like to thank. The studies were partly funded by NCBiR project No PBS2/A2/16/2013. Furthermore, the second author is sponsored by China Scholarship Council (CSC).

\section{REFERENCES}

[1] ApPoloni C.R., Fernandes C.P., RodRigues C.R.O., X-ray microtomography study of a sandstone reservoir rock, Nuclear Instruments and Methods in Physics Research Section A: Accelerators, Spectrometers, Detectors and Associated Equipment, 2007, 580(1), 629-632, DOI: 10.1016/ j.nima.2007.05.027.

[2] Baker D.R., Mancini L., Polacci M., Higgins M.D., Gualda G.A.R., Hill R.J., Rivers M.L., An introduction to the application of X-ray microtomography to the threedimensional study of igneous rocks, Lithos, 2016, 148, 262-276, DOI: 10.1016/j.lithos.2012.06.008.

[3] Beckers E., Plougonven E., Roisin C., Hapca S., LÉONARD A., DEGRÉ A., X-ray microtomography: A porositybased thresholding method to improve soil pore network characterization?, Geoderma, 2014, 219-220, 145-154, DOI: 10.1016/j.geoderma.2014.01.004.

[4] Bielecki J., Jarzyna J., Bożek S., LeKKi J., Stachura Z., KWIATEK W.M., Computed microtomography and numerical study of porous rock samples, Radiation Physics and Chemistry, 2013, 93, 59-66, DOI: 10.1016/ j.radphyschem.2013.03.050.

[6] Cesareo R., Assis J.T. DE, Crestana S., Attenuation coefficients and tomographic measurements for soil in the energy range 10-300 keV, Applied Radiation and Isotopes, 1994, 45(5), 613-620, DOI: 10.1016/0969-8043(94)90205-4.

[7] Chase G.D., RABINOwitz J.L., Principles of radioisotope methodology, Burgess Publishing Co. Minneapolis, USA 1968.

[8] CORMACK A.M., Representation of a function by its line integrals, with some radiological applications, Journal of Applied Physics, 1963, 34(9), 2722-2727.
[9] Cnudde V., Boone M.N., High-resolution X-ray computed tomography in geosciences: A review of the current technology and applications, Earth-Science Reviews, 2013, 123, 1-17, DOI: 10.1016/j.earscirev.2013.04.003.

[10] Dvorkin J., DerZhi N., FANG Q., NuR A., Nur B., Grader A., BALdwin C., Tono H., Diaz E., From micro to reservoir scale: Permeability from digital experiments, The Leading Edge, 2009, 28, 1446-1452.

[11] Hoek E., Carranza-Torres C., Corkum B., Hoek-Brown failure criterion, Proceedings of NARMS-Tac. Conference, 2002, 267-273, Toronto, Canada.

[12] Itasca (2015). PFC3D v5. 0-user manual. Itasca Consulting Group, Minneapolis, USA.

[13] KaCZMAREK Ł., ŁUKASIAK D., MaKSIMCZUK M., WEJRZANOWSKI T., Wykorzystanie wysokorozdzielczej mikrotomografii komputerowej oraz analizy ultradźwiękowej $w$ charakterystyce struktury paleozoicznych gazonośnych tupków z basenu baltyckiego, Nafta-Gaz, 2015, 71(12), 1017-1023, DOI: $10.18668 / \mathrm{NG} 2015.10$.

[14] KaczmareK Ł., MAChOWSKI G., MaKsimczUK M., WEJRZANOWSKI T., Strukturalna analiza mioceńskich piaskowców z zapadliska przedkarpackiego za pomoca wysokorozdzielczej mikrotomografii komputerowej, Nafta-Gaz, 2015, 71(9), 647-654.

[15] KaCzMAReK Ł., KozŁowsKa A., MaKsimczuK M., WEJRZANOWSKI T., The use of X-ray computed microtomography for graptolite detection in rock based on core internal structure visualization, Acta Geologica Polonica, 2017, 67(2), (in press), DOI: 10.1515/agp-2017-0010.

[16] Kaplan I., Nuclear Physics, Addison-Wesley Publishing Co., Reading, USA, 1963.

[17] Ketcham R.A., CARlson W.D., Acquisition, optimization and interpretation of $x$-ray computed tomographic imagery: Applications to the geosciences, Computers and Geosciences, 2001, 27(4), 381-400.

[18] KRZYŻAK A., KACZMAREK Ł., Comparison of the efficiency of $1 H N M R$ and $\mu C T$ for determining the porosity of the selected rock cores, 16th International Multidisciplinary Scientific Geoconference GREEN SGEM, 2016, Vol. 4, 81-88. SGEM, DOI: 10.5593/SGEM2016/HB14/S01.011.

[19] Li X., KoniETZKY H., Li X., Numerical study on time dependent and time independent fracturing processes for brittle rocks, Engineering Fracture Mechanics, 2016, 163, 89-107, DOI: 10.1016/j.engfracmech.2016.08.008.

[20] Mirvis S.E., Applications of magnetic resonance imaging and three-dimensional computed tomography in emergency medicine, Annals of Emergency Medicine, 1989, 18(12), 1315-1321, DOI: 10.1016/S0196-0644 (89)80268-9.

[21] Nabialek M., Bloch K., Szlazak K., Szota M., Magnetic properties and microstructure of a bulk amorphous Fe61Co10Ti3Y6B20 alloy, fabricated as rods and tubes, Materiali in Tehnologije, 2016, 50(2), 189-193, DOI: 10.17222/mit.2014.144.

[22] OLDENDORF W.H., Isolated flying spot detection of radiodensity discontinuities-displaying the internal structural pattern of a complex object, IRE Transactions on Bio-Medical Electronics, 1961, 8, 68-72.

[23] Oszczypko N., Krzywiec P., Popadyuk I., Peryt T., Carpathian Foredeep Basin (Poland and Ukraine): Its Sedimentary, Structural, and Geodynamic Evolution, [in:] J. Golonko, F.J. Picha (Eds.), The Carpathians and their foreland: Geology and hydrocarbon resources, AAPG Memoir, 2006, 84, 293-350. 
[24] Paszkowski M., PoręBSki S.J., Warchol M., Koncepcja projektu otworu kierunkowego $w$ mioceńskich utworach zapadliska przedkarpackiego, Wiadomości Naftowe i Gazownicze, 2009, 3(131), 4-13.

[25] Petchsingto T., Karpyn Z.T., Deterministic Modeling of Fluid Flow through a CT-scanned Fracture Using Computational Fluid Dynamics, Energy Sources, Part A: Recovery, Utilization, and Environmental Effects, 2009, 31(11), 897-905, DOI: $10.1080 / 15567030701752842$.

[26] Pstrucha A., Machowski G., KrzyŻAK A.T., Petrophysical characterization of the miocene sandstones of the carpathian foredeep (south-east Poland), 16th International Multidisciplinary Scientific Geoconference GREEN SGEM, 2016, Vol. 3, 891-898, SGEM, DOI: 10.5593/SGEM2016/B13/S06.112.

[27] Rybak A., Rybak A., Kaszuwara W., Awietjan S., JAROSZEWICZ J., The rheological and mechanical properties of magnetic hybrid membranes for gas mixtures separation, Materials Letters, 2016, 183, 170-174, DOI: 10.1016/ j.matlet.2016.07.078.

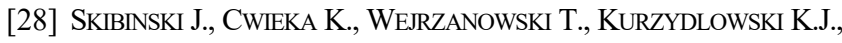
Design of mechanical properties of open-cell porous materials based on $\mu C T$ study of commercial foams, In MATEC Web of Conferences, 2015, 30, 03005-p.1-03005-p.5, DOI: 10.1051/ matecconf/20153003005.

[29] Wejrzanowski T., Haj Ibrahim S., Cwieka K., Milewski J., KURZYDLOWSKI K.J., Design of open-porous materials for high-temperature fuel cells. Journal of Power Technologies, 2016, 96(3), 178-182.

[30] Zhao Y., LiU Sh., Zhao G., Elsworth D, Jiang Y., Han J., Failure mechanisms in coal: Dependence on strain rate and microstructure, Journal of Geophysical Research: Solid Earth, 2014, 119(9), 6924-6935. 